Swarthmore College

Works

$11-15-2012$

\title{
Materializing Monsters: Aurora Models, Garage Kits And The Object Practices Of Horror Fandom
}

\author{
Bob Rehak \\ Swarthmore College, brehak1@swarthmore.edu
}

Follow this and additional works at: https://works.swarthmore.edu/fac-film-media

Part of the Film and Media Studies Commons

\section{Recommended Citation}

Bob Rehak. (2012). "Materializing Monsters: Aurora Models, Garage Kits And The Object Practices Of Horror Fandom". Journal Of Fandom Studies. Volume 1, Issue 1. 27-45. DOI: 10.1386/jfs.1.1.27_1 https://works.swarthmore.edu/fac-film-media/45

This work is brought to you for free by Swarthmore College Libraries' Works. It has been accepted for inclusion in Film \& Media Studies Faculty Works by an authorized administrator of Works. For more information, please contact myworks@swarthmore.edu. 


\title{
Materializing Monsters:
}

Aurora Models, Garage Kits, and the Object Practices of Horror Media

\author{
Bob Rehak
}

\section{SCALE MODEL FRANKENSTEIN MONSTER}

ALL PLASTIC ASSEMBLY KIT

YOU ASKED FOR IT-ANO HERE IT IS: A COMPLETE KIT of moided styrene piastic to assemble the worid's most faMOUS MONSTER - Frankenstein! A total of 25 separate pieces go into the making of this exciting. perfectly.scaled model kit by Aurora, quality manutacturer of scal model hobby sets. The FRANKENSTEIN MONSTER stands over 12 -inches when as. sembled. You paint it yoursell with avick. dry enamel, aod when finished the mear. ing figure, of the great monster apoears to walk reth off the cravestone hase that is part of the kit.
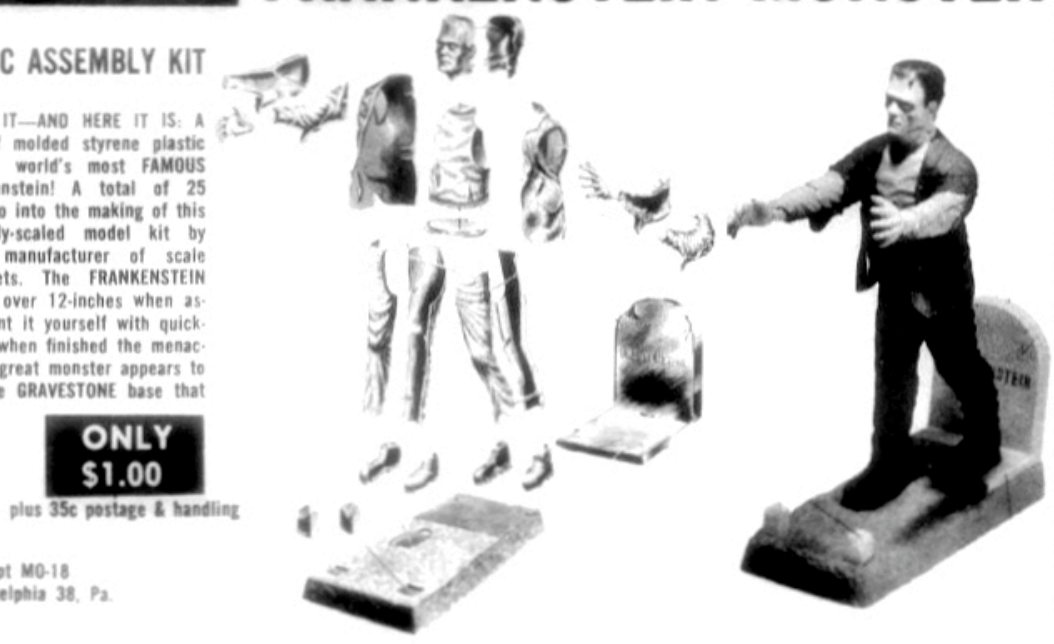

CAPTAIN CO. Dept Mo-18

Box 6573, Philadelphia 38. Pa

Figure 1

The July 1962 issue of Famous Monsters of Filmland carried an advertisement for a new product from Aurora Plastics Company: a scale model of Frankenstein's Monster (Figure 1). Announcing the first in what would become a long-running and profitable line of Aurora kits based on classic horror-movie creatures, the ad copy, running beside an exploded view of the model's individual parts alongside a finished and painted version, emphasized rather than elided the steps required to make it whole:

YOU ASKED FOR IT — AND HERE IT IS: A COMPLETE KIT of molded styrene plastic to assemble the world's most FAMOUS MONSTER - 
Frankenstein! A total of 25 separate pieces go into the making of this exciting, perfectly-scaled model kit by Aurora, quality manufacturer of scale model hobby sets. The FRANKENSTEIN MONSTER stands over 12-inches when assembled. You paint it yourself with quick-dry enamel, and when finished the menacing figure of the great monster appears to walk right off the GRAVESTONE base that is part of this kit.

Taken with its insistent second-person you, the text's avowal of "kit-ness" suggests that the appeal of monster models stemmed not just from their iconic content, but the way they promised to transform readers into modelers in a mutually reinforcing relationship of agency, much as the otherwise static and nonarticulated plastic monster would appear to "walk right off" its base. (Even the choice of subject held a felicitous symmetry: Frankenstein's Monster, in both the 1818 Mary Shelley novel that originated it and the 1931 film adaptation that supplied its most recognizable rendering, was pieced together from dead components - an act of promethean assembly whose fulcrum was precisely the animate/inanimate divide.) Although Aurora's creature kits of the 1960s were by no means the first commercial artifacts whose appeal was predicated on their close resemblance to the make-believe of popular culture, they marked an important turn in the evolution of such objects, merging the domains of mass and personal production and offering monster fans the opportunity to realize, with three-dimensional presence and heft, the media fictions in which they were invested.

Some fifty years later, to visit a typical comic-book shop is to encounter a cornucopia of Aurora's descendents: dramatically posed monsters cast in polystyrene, resin, and vinyl; busts and figurines of superheroes and aliens; articulated action figures of robots, wrestlers, and rock stars; gaming miniatures in the shape of dragons, wizards, and sentient battle tanks. Ranked in 
their glass cases and deployed across tabletop battlefields, these colorful bodies form a material halo around the printed comics, graphic novels, magazines, and reference guides that are the store's ostensible reason for existence. Physical extrusions of the artwork in comic books and graphic novels, movies and television (especially animation), and videogames and tabletop games are inescapable features of our crowded popular culture. Only recently, however, has this class of objects emerged from the marginalized categories of crude toy or crass tie-in to assume a key role in transmedia storytelling and blockbuster franchises, whose coordinated networks of fictional storyworlds and licensed merchandising seek to establish cultural ubiquity and plural revenue streams for expensively-produced and technologically-advanced entertainment properties (Gray; Jenkins; Johnson; Wasko and Shanadi).

In the sheer plenitude of its solid forms, the current mediascape can seem a bewildering ocean of stuff, especially when one considers the semiotic and ideological freight borne by these transubstantiated fictions. Blurring the ontological distinction between screen texts and solid objects, fantasy-media artifacts also blur dividing lines between amateurs and professionals, private and public, creativity and exploitation. But the situation's complexity is reduced at least somewhat when we isolate one of its historical tributaries, 1960s "monster culture," in which Aurora's creature kits and the wave of artifacts they emblematized - from commercial products to do-it-yourself costumes and make-up - marked the emergence, in embryo, of contemporary fantastic media and their associated artifacts. Facilitated by Famous Monsters and shared by a subculture of baby boomers in their preteen and teenaged years, the constructive activities of $60 \mathrm{~s}$ horror fandom laid both a generational and physical groundwork for today's transformative, franchised, materialized media culture. 
This essay explores the evolution of what I will call object practices from Famous Monsters to the present day. I begin in the early 1960s, when a convergence among TV programming, film exhibition, and a burgeoning market in horror-themed commodities found its focus in Aurora and Famous Monsters' mail-order division, Captain Company, refashioning the scale plastic model into a totem of horror-movie fandom. I then turn to the creative contests coordinated by Famous Monsters during that decade to demonstrate the metamorphic, generative potential of monster objects in amateur filmmaking. Finally, I discuss the rise of garage kits and the collectibles market in the 1980s and 1990s, when an aging generation of boomers began to reinvent the artifacts of their childhood in newly sophisticated and profitable forms. Although my study is organized chronologically, its goals extend beyond straightforward historical narrative to sketch a theory of fantasy-media-based objects and the practices that embed them in culture - suggesting a corrective to media scholarship that too often emphasizes the texts of film, $\mathrm{TV}$, and gaming while losing sight of the material forms these texts assume in lived experience.

\section{THE RISE OF MONSTER CULTURE}

Along with Famous Monsters of Filmland, Aurora kits were at the epicenter of what Kevin Heffernan describes as "an explosion of horror-related media and merchandising in the mid-sixties" that included "trading cards, LP records of old horror radio shows, $8 \mathrm{~mm}$ homemovie versions of the Universal classics, monster magazines, and reprints of fifties horror comics" (212). In his history of horror cinema and its reception in America, David J. Skal underscores the diffuse social nature of the phenomenon: 
In Monster Culture, the participatory rituals surrounding the movies were every bit as important as the films themselves. The rites included the shared witnessing of the antics of horror hosts; an explosion of fan magazines that were read, reread, and traded among the cognoscenti; and even the creation of plastic model effigies. Most important, monsters materialized in the living room for the first time - not just reflected in the movie theaters, but now a light source, a glowing electronic fireplace around which a generation could huddle and shudder and share. (266267)

The "glowing electronic fireplace" to which Skal refers is, of course, television, one of several factors that came together in the decades following the end of World War II to resurrect the horror genre and foment new forms of engagement with the images and objects of monster culture. The 1950s had seen a fresh wave of science-fiction and horror film production in the United States, Britain, and Japan, whose emphasis on giant creatures mutated by radiation and sinister alien invasions of home and community reflected Cold War fears of nuclear armageddon and the perceived Communist threat (Biskind). Starting in 1957, with Terence Fisher's The Curse of Frankenstein, Hammer Studios in England began reimagining classic horror film properties in Technicolor, following a trend of new exhibition modalities such as widescreen and 3D. That same year, Screen Gems, the syndication arm of Universal Pictures, sold its "Shock Theater" package of horror movies to broadcast TV affiliates and independent stations in New York, Philadelphia, and other large metropolitan markets, restoring to circulation a catalog of films from Universal's golden age of horror, including Dracula (Tod Browning, 1931), Frankenstein (James Whale, 1931), The Mummy (Karl Freund, 1932), The Wolf Man (George Waggner, 1941), and their many sequels (Heffernan 155-179). 


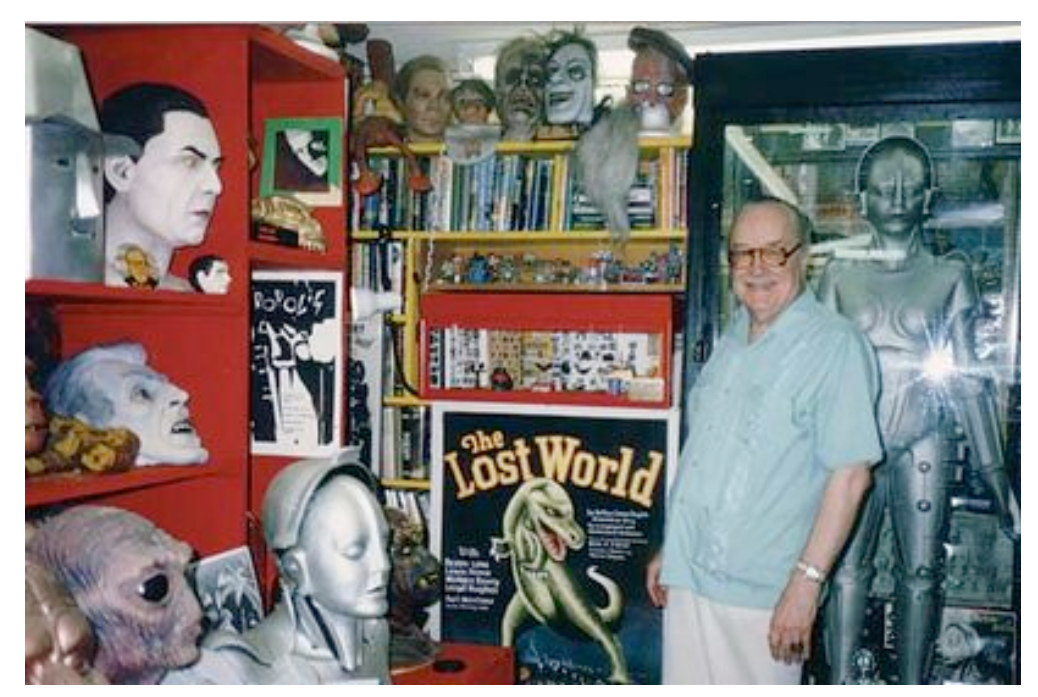

Figure 2

Young audiences encountered these films largely through the intermediary of Famous Monsters and its editor, Forrest J Ackerman, whose punning, avuncular style mirrored the personae of local TV "horror hosts" like Vampira in Los Angeles and Zacherley in Philadelphia. Ackerman, himself a fan and collector, exemplified a playful but fiercely acquisitive approach to horror: the memorabilia-stuffed "Ackermansion" in which he lived featured frequently in the magazine, and in combination with editorial content - heavy on behind-the-scenes anecdotes and profiles of special-effects technicians - suggested a contiguity between insider knowledge and the ownership/display of objects (Figure 2). The 1958 inaugural issue of Famous Monsters hawked a smattering of gag novelties (rubber skeletons, bats, and spiders; plastic vampire fangs; a "werewolf siren ring") that could be found in most comic books of the time. But by its twelfth issue in June 1961, the magazine's mail-order arm, Captain Company, was offering items that ranged from rubber face and full-head monster masks to $8 \mathrm{~mm}$ reels of abridged horror classics such as The Phantom of the Opera (Rupert Julian, 1925), The Bride of Frankenstein (James Whale, 1935), and The Creature from the Black Lagoon (Jack Arnold, 1954). 
Aurora's intersection with Famous Monsters came about when the company turned to horror-movie characters in a quest to develop new products that would appeal to the modelbuilding community. Originally a plastics fabricator based in Long Island, Aurora spent the first part of the 1950s manufacturing simple toys such as a bow-and-arrow set (Graham 6). Its first model kits, like those of competitors Revell and Monogram, were of submarines, fighter planes, and sailing ships: real-world items scaled down to miniature form and broken into pieces for assembly and painting by the kit's buyer. In 1957, Aurora introduced a line of "figure kits" in the shape of people, based on the most generic of types - "Bride and Groom," "Swiss Boy and Girl," "Apache Warrior" - which enjoyed only brief popularity (29). Searching for fresh concepts, Aurora advertising executive Bill Silverstein was inspired by the prominence of horror on TV and in movie theaters to develop a prototype based on Frankenstein's Monster, licensing the proprietary image from Universal. His co-workers were dubious, but when the first monster kit received an enthusiastic response from the children of attendees at a Chicago trade show in January 1962, the monster was rushed into production (39). The first Aurora ads appeared in Famous Monsters in July of that year, and by the end of 1962, two other Universal characters, Dracula and the Wolf Man, had joined the lineup.

Models begin as unique sculptures in wax or clay which are then cut apart and arranged into flat, gridlike trees on a metal die called a "tooling." Once a tooling has been created, hot polystyrene is flowed through its channels in a process known as injection molding, stamping out multiple, identical copies. The initial stages of design, sculpting, and tooling tend to be prolonged and expensive; mass production of kit parts from an existing template, by contrast, rapid and cheap. This oscillation between the singular and the serial is characteristic of the figure kit's larger trajectory through its lifespan as prototype, artifact, commodity, and final 
(re)construction in the hands of its owner; an Aurora monster kit crystallized (or "plasticized") the individual talents of sculptors like Bill Lemon and box-cover artists like Larry Bama as much as the technologies of manufacture and distribution that made the model and its associated artwork available in large numbers to a young population of kit-building monster fans - each of whom, in turn, could fashion from identical sets of parts a unique and personally significant object.

Through 1968, Aurora's monsters grew in number to thirteen, including Dr. Jekyll as Mr. Hyde, the Hunchback of Notre Dame, King Kong, Godzilla, as well as two figures drawn from no specific source, the Witch and the Forgotten Prisoner of Castel-Mare. With a few exceptions, all were molded in 1/8 scale (one inch of model equaled eight in "real life," a nine-inch model standing in for a six-foot monster). Most drew carefully on screen reference, with the Universal subjects in particular traceable to the designs of the studio's key make-up artist in the 1930s and 1940s, Jack P. Pierce. Kits based on other fantasy-media properties such as superheroes Superman and Batman soon joined the catalog, cross-advertised in issues of DC Comics; similar synergies led to models based on TV series including the Irwin Allen productions Voyage to the Bottom of the Sea (1964-68), Lost in Space (1965-68), and Land of the Giants (1968-70). As the decade waned, Aurora sought to differentiate its monster line, reissuing older kits in glow-in-thedark plastic and experimenting unsuccessfully with "Monstermobiles" (which crossed monsters with another fad, hot rods). In 1971, one particularly prurient kit - The Victim, a half-dressed young woman in a pose of terror - drew protests from the National Organization of Women, prompting Aurora to withdraw the entire line of mix-and-match "Monster Scenes" to which it belonged. Yet even amid these stumbles, creature kits remained far and away Aurora's best 
sellers, making the company throughout the 1960s and into the early 1970s the world's largest hobby manufacturer (Graham 6).

Monster culture emerged during a new chapter in the social history of toys and hobbies in the United States. The rise of TV as a mass medium, combined with the prosperity of the American middle class and the arrival of the baby boom generation, came together in the chronotope of the suburban home, populated by a nuclear family whose leisure time was structured by new categories of media-inflected play. In October 1955, Walt Disney's Mickey Mouse Show premiered, the first TV series whose content and advertising were aimed squarely at children (Chudacoff 154). Along with future giant Mattell, one of the show's sponsors was Hasbro, whose Mr. Potato Head epitomized the new breed of commodified, industrialized toy: made of colorful plastic, manufactured and distributed in huge quantity, marketed on TV, and intended for free - as opposed to educational - play (7). Unlike the toys popular with previous generations, such as wagons, Erector Sets, and Raggedy Ann dolls, toys of the 1950s hailed a growing population of preteens as a group with interests and tastes distinct from, and potentially antithetical to, those of their parents.

In certain ways, monster objects complicated these trends. Resurrecting in painted polystyrene a gallery of creatures from films popular in the 1930s and 1940s, they served to connect postwar children with the childhood fascinations of their parents, and it is not difficult to imagine a multigenerational audience gathered around the "glowing electronic fireplace" in simultaneous rituals of reminiscence and initiation. In other ways, however, monster culture moved with the grain of ideology, most explicitly in its gendering of play. Classically visible in the cartoonish dimorphism of Barbie (1959) and G. I. Joe (1964), the distinctiveness of "boy culture" from "girl culture" lies in part in its emphasis on making and building, as well as its 
embrace of the violent and disgusting: qualities epitomized in Aurora's creature kits, which offered a pleasurable frisson of the fearsome yet controllable, the abject yet ownable. While its boundaries were certainly porous, as evidenced by the many female readers featured in Famous Monsters' fan-club coverage, monster culture in its formative roots as well as its later years seems dominantly a pastime of the (middle-class, white, presumably straight) male, and the skills, predilections, and orientations it inculcates - particularly as they play out on a scale of decades - should not be viewed in isolation from questions of male identity, power, and privilege.

Steven M. Gelber situates the development of kits - referring to any prepackaged set of parts requiring assembly - along a timeline of crafting and collecting that dates back to the late nineteenth century, when social and economic changes in the workplace led to a colonization of domestic space and time by handicrafts (3). For Gelber, the rising popularity of kits in the postwar era was an unfortunate development, facilitating hobbyists' productivity but curtailing their creativity (262). In his view, because one could only build a kit into its intended object, and because this process required nothing more than the following of instructions, kits represented the Taylorization just of leisure time but imaginative potential, turning hobbies (sometimes literally) into paint-by-numbers activities, "no more art than gluing together a plastic model was a craft." (263) The popularization of plastic kits represented "the ultimate victory of the assembly line," contrasting sharply with an earlier era of true creativity in which amateur crafters "sought to preserve an appreciation for hand craftsmanship in the face of industrialization." (262263) Gelber's thesis about the gradual narrowing of children's imaginations by industrialized hobbies parallels critics of children's media culture in general, who see the narratives and imagery promulgated by comic strips, radio, TV, and movies as "scripts" dictating the proper 
way to play: a disciplining of youthful subjectivity whose culprit is the toy based on and marketed by media (Chudacoff, Kline, Linn).

Gelber's history of hobbies in America stops around 1950, at a pivotal shift from the kinds of kits that dominated the first half of the $20^{\text {th }}$ century - miniature airplanes and boats, usually constructed of balsa wood - to plastic models whose referents were fictional subjects. (The first all-plastic kit was in fact an early kind of media tie-in: in 1951, Revell, a Californiabased toy company, had its first commercial success with a 1910 Maxwell automobile made famous by comedian Jack Benny's radio [later TV] show [Kerr 84].) But if prefabricated toys of the 1930s and 1940s based on fantasy characters such as Superman, Dick Tracy, and Mickey Mouse had represented the colonization of children's play by mass media, model kits introduced a new term to the equation: the opportunity for personal involvement at the level of assembly, painting, detailing, and modification by the builder. Although for Gelber the plastic model was an imaginative dead end, its meanings and pleasures as circumscribed as its final shape, Aurora's "effigies" solidified a more subtle, and as we shall see fertile, interdependence between media consumption and production. Monster-kit builders took the pieces provided by popular culture and transformed them through their labor into artifacts that were simultaneously unique and collective, constructing themselves as skilled subjects in the process of constructing their creatures. Even as object practices of the 1960s and 70s moved beyond plastic figures to encompass other forms of production and reproduction, Aurora's models remained an anchoring metaphor for the fantasy-media object's complex operations. 


\section{THE OBJECT/TEXT ECOSYSTEM}

The back cover of the March 1964 issue of Famous Monsters was devoted to a colorful collage of Aurora monsters announcing a competition in which readers would not just build Aurora kits, but modify and submit them for judging at local hobby shops. Inside the cover were the details:
All it takes is a little nerve \& imagination. Buy one of Aurora's Movie Monster Model Kits, assemble it, paint it, and start your customizing! Anything goes! For instance - Frankenstein could use real bolts and wires; give the Wolfman real hair; wrap the Mummy in real cloth; add creepy effects from Aurora's “MONSTER CUSTOMIZING KIT.”

In the article on the winning entries that ran a year later, prize winners' names and photographs accompany photographs of their creations: plastic monsters combined with each other to make dioramas - caves, laboratories, castle dungeons, city streets - detailed with handmade props and painted backdrops (Figure 3). Embedded in three-dimensional space, the creatures seem to return to their cinematic roots, but their mise-en-scéne is at once familiar and novel, presenting events never pictured in any movie: Count Dracula performing surgery on Frankenstein's Monster; Quasimodo assisting the Phantom of the Opera; the Mummy swinging open the cover of his sarcophagus into which the Creature from the Black Lagoon is about to blunder. 


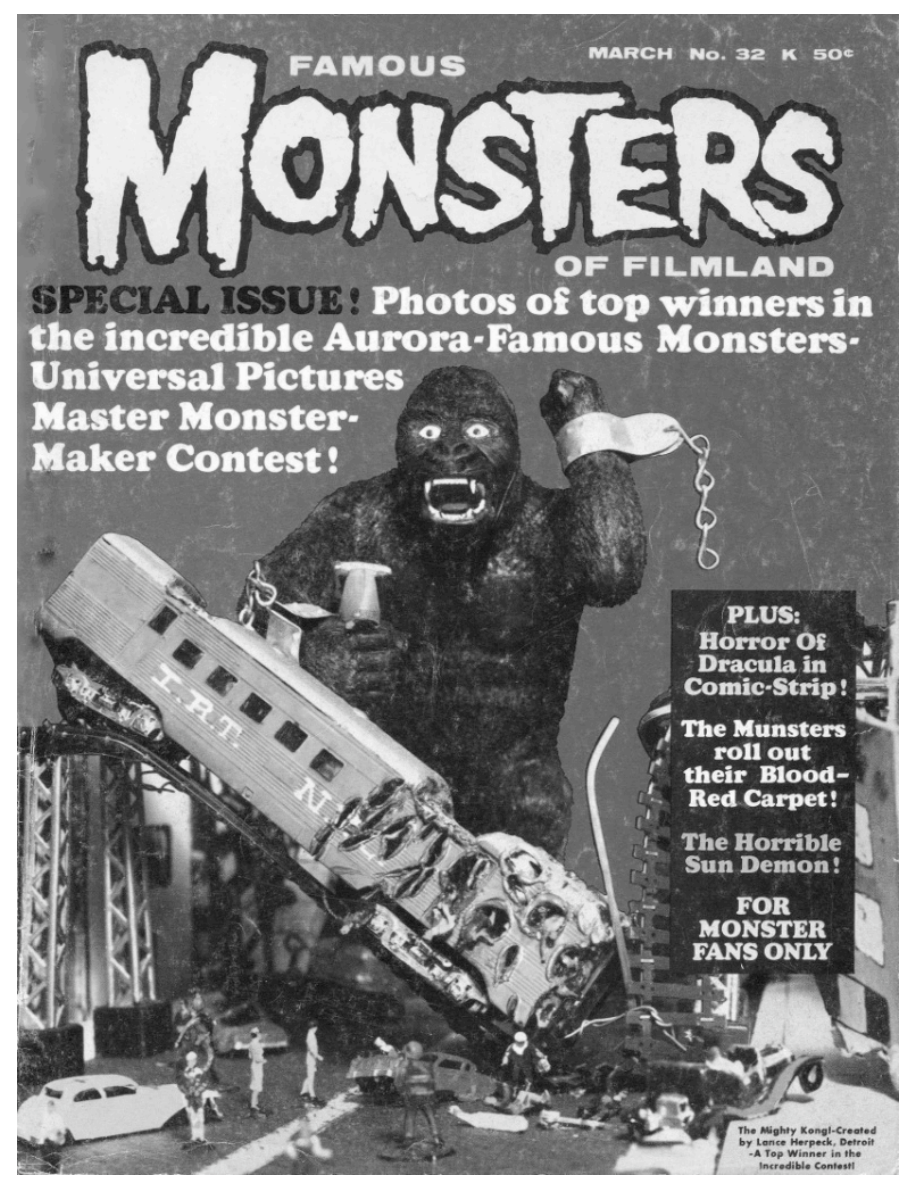

Figure 3

While not precisely falling under the category of "transformative works" that would later come to dominate discussions of fan creativity, the model contest of 1964 highlights the multivalent potential of object practices, material "mashups" in which characters and settings were reconfigured into novel situations years before slash fiction and vidding became a defining activity of Star Trek and other fandoms (Coppa). In this way, the model contest merely formalized the kinds of playful creativity already rampant in Famous Monsters' pages, where photo collages, humorous captions, games, and quizzes extended to readers an implicit invitation to seize and remake monster culture according to their own amusement and interests. That this ludic sensibility profited the magazine and its brand partners (the model contest, for example, 
was sponsored jointly with Aurora and Universal) does not negate its inherently transformative spirit or the generative potential of object play, wherein fantasy-media artifacts exist not as the static endpoint of a commercial transaction but as linkages in what we might call an object/text ecosystem: bristling networks of authorship, appropriation, and translation whose nodes include the production of new and original content.

Along with other competitions organized by Famous Monsters, including make-up and amateur film challenges, the model contest of 1964 reflects the magazine's early encouragement of what Anne Jarslev, writing of Peter Jackson's Lord of the Rings adaptation, labels “artifact emotions" toward fantastic media, in which appreciation of cinematic spectacle - here, the vivid iconography of movie monsters - is paired with knowing admiration for the technical craft that went into its making (214-215). By focusing much of its editorial content on special effects techniques and auteurs, Famous Monsters constantly emphasized the manufactured nature of the films it covered; with its various contests, it coaxed readers into active roles as creators; and through the materials sold by Captain Company, it provided tools to assist in that process of creation, both onscreen (from creepy props of human skulls and flying bats to full-fledged makeup kits) and behind the scenes (movie cameras and projectors). Perhaps most importantly in the years before playback technologies such as videocassettes, DVDs, and Blu-Rays became a commonplace method of revisiting and studying cherished films, Famous Monsters and other monster-culture publications of the 1960s constituted an archive of still photographs and artwork, freezing for extended scrutiny the ephemeral flow of images across video and movie screens. This trove of reference material, an instance avant la lettre of contemporary "replay culture" (Klinger 3), served as more than just a terminus of contemplation, inspiring and guiding the production of new horror media through a play of objects. 
As Michele Pierson has noted, many readers of special-effects-oriented fanzines in the 1960s and 1970s harbored hopes of becoming professional filmmakers themselves, often making their own $8 \mathrm{~mm}$ and $16 \mathrm{~mm}$ movies (67). Famous Monsters' popularity coincided with what Clive Young has characterized as a "mass influx of movie cameras into postwar life," a generation of baby boomers who as they entered adolescence "put Mom and Dad's new toy to work, fashioning their own movies that were inevitably inspired by what they were seeing at the local movie theater each weekend: monsters, spaceships, aliens, superheroes, and more." (29; see also Zimmerman 112-142) In October 1963, the magazine sponsored its own amateur home-movie contest, offering mediacentric prizes such as a Sony portable TV set, an 8mm camera, and a Polaroid Land camera. Evidence of the magazine's close and unapologetic interlock with the creative processes of its readers can be found in the contest's format. Entries had to be based on one of two scripts provided by the editors for a price (four dollars). The first, "Twin of Frankenstein," was pitched as a simpler (and, we should note, gendered) task:

With a little adult help, an 8-year-old boy should be able to film it. Step by step, the script tells you what to film. It is up to you \& your imagination, your talent, your creativity, your ambition, to produce the version with the best make-ups, lighting effects, angles, etc.

The second script, "Siegfried Saves Metropolis!”, was more demanding:

Script \#2 will offer a challenge to the older, more experienced filmmakers, those who want to "test their mettle" (there's a robot \& a dragon to build \& animate!) on some tabletop work, models, animation, etc. 
As the latter description suggests, within the fertile culture of amateur fantasy media, objects related to special-effects production played a privileged role, none more so than the tabletop "robots and dragons" in which Famous Monsters' adoring coverage and the filmmaking goals of readers converged. Although the special-effects departments of the major movie studios had been in decline since the late 1950s, "one area of visual effects production continued to attract fans with aspirations of working in the film industry: stop-motion animation." (Pierson 69) In this type of animation, articulated puppets built of rubber and other materials over a poseable metal armature are filmed frame by frame to produce the illusion of movement; various compositing methods are used to embed these figures in diegetic space. One of Forrest Ackerman's favorite films was King Kong (Merian C. Cooper and Ernest B. Schoedsack, 1933), an exemplar of stop-motion animation by pioneer Willis O'Brien; and if the magazine had a post-Kong visual-effects celebrity, it was Ray Harryhausen, whose work on films like The Beast from 20,000 Fathoms (Eugène Lourié, 1953), Earth vs. the Flying Saucers (Fred F. Sears, 1956), and The $7^{\text {th }}$ Voyage of Sinbad (Nathan Juran, 1958), had come to define both the 1950s "creature feature" and the much-publicized technical processes underlying it. A correlative to Jack Pierce's monster make-ups of the 1930s and 1940s, Harryhausen's dueling skeletons (from Sinbad) and Venusian "Ymir" (from 20 Million Miles to Earth [Nathan Juran, 1957]) provided readers with templates for building - and animating - their own monsters.

Few examples better demonstrate the entanglement of Famous Monsters, established and emerging filmmakers, and the object practices that connected them than the case of Dennis Muren, David Allen, and Equinox. In January 1962, Muren had appeared in the magazine's fan club newsletter, the Graveyard Examiner. "Horrors of the Muren Museum" showcased the teenager's collection of movie stills and posters, behind-the-scenes photos, shooting scripts, and 
back issues of Famous Monsters. Two issues later, in May 1962, the newsletter carried a personal ad from another teenaged reader, David Allen, addressed to fellow fans of King Kong and stop-motion animation. The ad brought together Muren, Allen, and another California-based friend, Mark McGee, to form a movie-viewing and discussion club. "Screenings were often held in McGee's home, with a 16mm projector and rented movies," writes Brock Deshane. "The boys also chewed over their own film experiments." (12) This ad hoc collective hatched a plan to make their own feature film, one they hoped would run on the late-night creature feature that had become an anchor of horror fandom on TV. The Equinox ... A Journey into the Supernatural (1967), filmed for $\$ 6500$ over a two-year span on weekends and summer vacations using a $16 \mathrm{~mm}$ Bolex, grew as much out of the materials available to the filmmakers as from the narrative codes of fantasy and horror genres. As Deshane notes,

[McGee's] ambitious yet budget-minded scenario, later augmented by Muren and Allen, was largely built around Allen's pre-existing stop-motion models of a Kong-inspired simian called Taurus, a skeleton straight out of Sinbad, and a sinister cephalopod reminiscent of Harryhausen's creatures in It Came from Beneath the Sea (1955) and Mysterious Island (1961). Using techniques pioneered by O'Brien and King Kong puppet maker Marcel Delgado, Allen assembled his models with jointed armatures and foam-rubber flesh. Tusked, tentacled, and bat-winged, with skins of blue and bloodred, the homemade homunculi looked as if they'd crawled from one of [Famous Monsters'] gloriously pulpish cover paintings. (12-13)

Muren and Allen's familiarity with the work of O'Brien and Harryhausen led them to create creatures based on those in the older films, embedding Equinox ... A Journey into the 
Supernatural in an intertextual quilt of homage (Figure 4). Their stop-motion puppets thus concretized an apprenticeship wrought through relays of visual content, including not just the films they had screened and watched on TV, but the reference materials provided by Famous Monsters and collected in personal archives like the "Muren Museum."

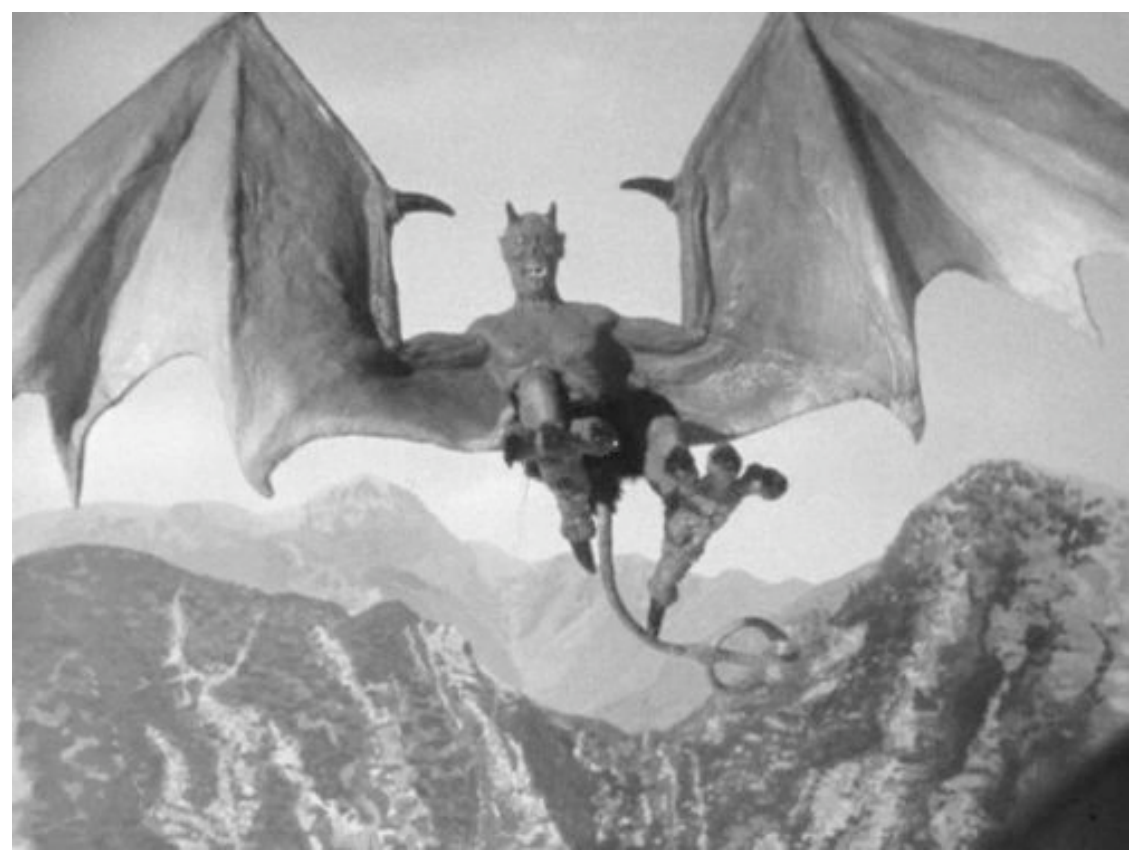

Figure 4

If the pages of Captain Company curated a continuum of monster objects, encompassing at one extreme the toylike approximations of inexpensive rubber masks or vampire fangs, and at another the detailed Aurora model kit and make-up set, the example of Equinox ... A Journey into the Supernatural suggests an even larger continuum framing 1960s monster media, in which layered arrays of objects and their associated practices were mobilized to produce short and feature-length films: potential gateways between amateur and professional spheres of production. Equinox ... A Journey into the Supernatural was purchased by producer Jack H. Harris, recut, and released as a feature film (titled simply Equinox) in 1970 that did indeed become a fixture of 
late-night horror-film showings on TV. Its filmmakers went on to work in the industry, in particular Muren, who ten years after the completion of Equinox played a central role in the visual-effects production of Star Wars (George Lucas, 1977) and continues as a dominant figure in special effects to this day. Several other filmmakers who came to prominence in the 1970s and 1980s, such as Lucas, Steven Spielberg, Joe Dante, and Peter Jackson, have cited Famous Monsters as a primary influence, materializing their fandom in experiments with $8 \mathrm{~mm}$ and Super-8 filmmaking. (Spielberg, whose short movie Firelight [1964] prefigured his Close Encounters of the Third Kind [1977], is especially evocative in this regard, further evidenced by his producer's credit on Super 8 [2011], J. J. Abrams's paean to Spielberg and the generation of amateur moviemakers who emulated him.)

One should, of course, approach such narratives of inspiration with caution, following John T. Caldwell's reminder that they constitute one strand of a self-perpetuating and often selfserving industrial discourse that in this case lends fan credibility and DIY ingenuity to the operations of media conglomerates (Caldwell). Other amateur filmmakers with roots in monster culture, such as Donald F. Glut, never rose to the same celebrity, instead living out careers on the periphery of the industry (Young 31-40), and even these stories of relative success are vanishingly rare when measured against the much larger number of readers and fans who did not attain professional filmmaking positions. However, it seems clear that some relationship existed between 1960s monster culture and the changes experienced by the movie industry over the next two decades, with Famous Monsters and the object practices it encouraged providing essential ingredients - in terms of industrial labor, the grooming of new audiences, and the economic coordination of surrounding industries of texts, toys, and tie-ins - for the blockbuster culture that emerged over this period, as the magazine's readership matured and the object practices of 
horror fandom became more technologically sophisticated and culturally pervasive in step with generational demand.

\section{GARAGE KITS AND COLLECTIBLES}

Ackerman's final issue as editor of Famous Monsters of Filmland appeared in January 1983, shortly before the magazine ended its twenty-five-year run. Ironically, Famous Monsters folded just as the culture of fandom it had helped to instigate was becoming a mainstream phenomenon, with science-fiction blockbusters of the late 1970s and early 1980s - in particular, the nascent production empires of George Lucas and Steven Spielberg - attracting huge audiences and profits, assisted by a tidal wave of tie-in toys and models. Famous Monsters's pages were by then thoroughly colonized by this shift in the fortunes of fantastic media: its cover story featured The Empire Strikes Back (Irvin Kershner, 1980), and Captain Company’s lineup was overwhelmingly Star Wars-themed, with books, blueprints, and LP records sharing space with plastic play sets and action figures based on Lucas's movie. Although a few other film and TV properties, such as Superman (Richard Donner, 1978), Alien (Ridley Scott, 1979), and Buck Rogers in the $25^{\text {th }}$ Century (1979-1981) were represented among the products, most of these were of recent vintage, with little classic horror content remaining. Only the continued presence of products related to the Star Trek franchise (1966-), which had itself spawned one of the most popular science-fiction model kits in history, AMT's U.S.S. Enterprise, tied Famous Monsters to its heyday.

Aurora too had fallen on hard times. Acquired by Nabisco in the early 1970s, the company foundered amid a more general crisis in the U.S. hobby industry, whose factors 
included a decline in the number of distributors and hobby shops, the aging of the baby boomers, and the rise of digital arcade games, personal computers, and videogame consoles madly popular with children (Graham 95). Following losses across all areas of Aurora's line, including games and slot cars, Nabisco broke up the company in 1977, selling many of its assets - toolings, reference materials, and artwork - to Monogram, then the second-largest model supplier behind Revell. Over the next several years, Monogram reissued a few of the Aurora monster kits, but to only moderate success, suggesting the market had been exhausted (96).

If monsters themselves no longer found favor with the public, other fantasy-media objects emphatically did. The arrival of Star Wars in 1977 ushered in a new era of licensed product tie-ins; as Jonathan Gray argues, the "voluminous paratextual entourage" that surrounded the franchise was not only a gold mine of merchandising, but offered audiences multiple points of entry into the fictional universe conjured by Lucas and his designers, providing fans with a means of engaging the narrative's large cast of characters as well as its omissions and ambiguities, while sustaining spectator interest during the intervals between new installments (177-187). Implicit in Gray's thesis is the notion that blockbuster franchises following in the wake of Star Wars, such as Alien, Indiana Jones (1981-), and Transformers (1984-) rely on physical incarnation as a means of preserving their popularity and commercial viability: a kind of grout filling in the gaps that are the unavoidable structural byproduct of serial media. From this perspective, the model of transmedia storytelling advanced by Henry Jenkins, in which a story "unfolds across multiple media platforms, with each new text making a distinctive and valuable contribution to the whole" (95-96), is an epiphenomenal outgrowth not just of convergence, but the ramifying ontologies of media themselves in the second half of the 
twentieth century, when materials manufacturing made it possible to realize, in newly accurate shapes, the circulating fictions of storytelling on a massively coordinated scale.

Paratextual approaches to media franchises, however, have less to say about the kinds of grassroots fabrication that began to arise around the time of Aurora's and Famous Monsters' demise, seemingly in answer to a blockbuster landscape whose products - while varied enough in form - confined themselves to the subject matter of a handful of dominant brands. The blossoming of SF and fantasy media in the late 1970s and early 1980s had created, as it were, a cult within the cult: fans enjoyed endless supplies of Star Wars and Star Trek paraphernalia, but far less access to niche materials based on one-shot films like Forbidden Planet (Fred M. Wilcox, 1956) and 2001: A Space Odyssey (Stanley Kubrick, 1968); dead TV series like The Invaders (1967-1968) or Kolchak: The Night Stalker (1974-1975); and media properties originating outside the U.S. like Doctor Who (1963-) and Space: 1999 (1975-1977).

To fill this need, a new class of fantasy-media object emerged: the garage kit (Figure 5). In Japan, model makers bored with the limited range of existing kits began to create their own figures, first sculpting them in clay, then making silicone-rubber molds of those sculptures and reproducing them using a number of different substances, including vinyl, PVC, resin, or epoxy (a process also known as cold casting). Taking their name from the isolated and aerated workspaces the messy, sometimes toxic chemistry required, garage kits were first produced individually and shared among close-knit fan communities (Webb). Soon, however, they evolved into small-scale businesses, with companies like Kaiyodo (which started in 1979), Billiken (1982), and Max Factory (1984) selling through mail-order and hobby shops kits based on kaiju (city-destroying behemoths such as Godzilla), mecha (giant human-piloted robots), Harryhausen creatures, and classic movie monsters such as the Bride of Frankenstein and the Metaluna 
Mutant from This Island Earth (Joseph M. Newman, 1955). When American fans discovered the Japanese kits, they were inspired to make their own sculptures and castings, sold through similarly small and specialized companies such as Screamin’ (1987), Halcyon (1988), GEOmetric (1989), and Dark Horse (1990).

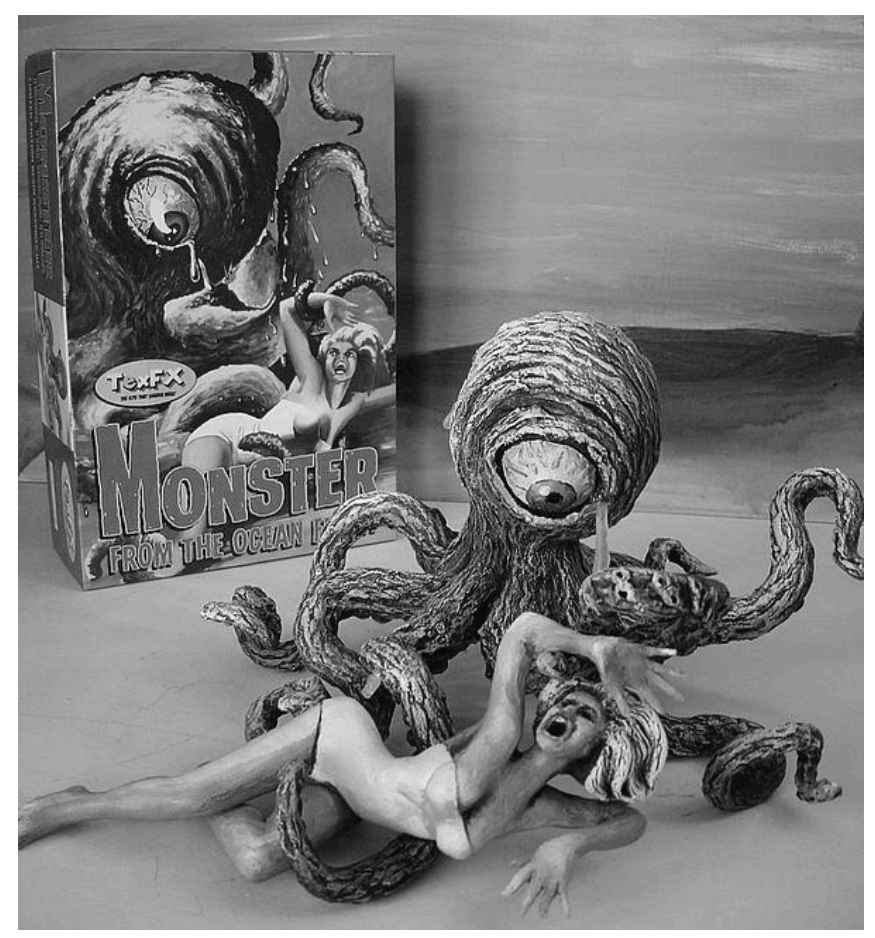

Figure 5

Garage kits continued to evolve throughout the 80 s and early 90 s as their popularity and profitability grew. 1994 was a particularly significant year, seeing the creation of two large companies, Macfarlane Toys and Sideshow Collectibles, that substantially expanded the variety and quantity of figures available. The same year, Terry J. Webb, a central player in the garage-kit world, launched Amazing Figure Modeler magazine, which consolidated the functions of a number of smaller fanzines devoted to modeling. Along with conventions devoted to toys, models, and collectibles such as Wonderfest in Louisville, Kentucky, and the biannual Chiller 
Theater in New Jersey, the figure market flared into mainstream visibility, with the rise of the World Wide Web and (in 1997) eBay acting as accelerants. A 1996 ad for the California-based company Monsters in Motion, for example, captures something of the figure-kit community's scope, offering statues and sculptures in categories such as "TV Memories" (Rod Serling from The Twilight Zone, Zanti Misfits from The Outer Limits, Daleks from Dr. Who); “Attack of BMovies" (Tor Johnson from Plan 9 from Outer Space, the scuba-helmeted gorilla Ro-Man from Robot Monster); and "Vehicles/Spaceship" (the Star Fury fighter from Babylon 5, the timetraveling DeLorean from Back to the Future, James Bond's Aston Martin DB5).

This micro-targeting of genre interests was driven both by the recirculation of cult archives in home-rental and bootleg media, which constantly refreshed subcultural memories of specific properties, and by the connoisseurial economics of the collectibles market. Busts and figurines are distinguished from toys and action figures principally by price and rarity; produced in much smaller numbers than mainstream media tie-ins, figure kits can cost anywhere from $\$ 50$ to $\$ 500$, with most falling into the $\$ 100-\$ 200$ range. Expense depends in part on a model's scale and consequently its size; in 1996, a 1:4 figure of Yoda sold for $\$ 63$, while a 1:1 "lifesize" Yoda cost $\$ 399$. Another factor in pricing is the degree of "finish" desired by the buyer. An unassembled kit costs less than a complete build-up, which in turn costs less than a finished and fully painted version.

The decades-long process by which figure kits evolved into collectibles thus involved the establishment of increments of displaced labor; under the protocols of capitalism, what had once been a solitary investment of time by the home modeler could now be farmed out to the talents of a remote builder. Recalling the layered semiosis of the Aurora kits that are their spiritual and aesthetic antecedents, each garage kit or collectible figure "points to" an onscreen referent, 
carefully basing its colors and textures on film or video reference, and deriving value from the degree to which it captures the subject's distinctive iconography. At the same time, each figure is imbued with attributes specific to their sculptors, from the broad gesture of a dynamic pose to a subtle detail of facial expression. Just as their cinematic and televisual referents themselves marked the compositing of creative input - the actor's, make-up artist's, costumer's, cinematographer's, and so on - figure kits condense multiple stages of artistry and technique, sedimenting within themselves the additional contributions of sculptors, painters, and manufacturers.

Recent years have seen the establishment of companies like Polar Lights and Moebius that reissue older plastic models such as Aurora's creature kits. In some cases, these kits are produced using the original toolings; where the toolings have been damaged or destroyed, models are sometimes reverse-engineered for injection molding, vintage kits broken apart so that their component pieces can be recast. Taken together with the phenomenon of bootlegs (unlicensed figures copied from existing kits and sold at lesser cost), the endlessly iterated and "rebirthable" nature of the figure kit highlights a tension central to the fantasy-media object's identity and its circulation within overlapping economies of monetary and subcultural capital: paired tendencies toward the stasis of the singular and the flow of the serial that together render this class of artifacts peculiarly motile across the spacetime of late capitalism. In a quite literal sense, the fantasy-media object is Walter Benjamin's work of art in the age of its mechanical reproducibility. 
Conclusion: Taking on the Icons

In July 2010, a glossy publication appeared on newsstands, its cover adorned with a colorful Basil Gogos painting of Bela Lugosi in his iconic role as Count Dracula. Under Lugosi's portrait ran a banner announcing The Return of the World's First Monster Fan Magazine! Resurrected after Forrest J Ackerman's death in 2008, the official relaunch of Famous Monsters promised to continue the magazine's tradition as "a conduit for undiscovered talent and future giants" that would "again touch fandom through treasures, events, and partnerships" (Kim and Heisler). As though to balance this opening invocation of new-media virality with its historical antecedent, the issue closed with a revamped Captain Company advertising section full of sexily fanged, Goth-complexioned models, selling apparel such as the "Night of the Living Dead Fitted Women's Tee” and “Famous Monsters Embroidered Fleece Full Zip Hoodie” alongside commemorative coins, silk prints of Ackerman, and collectible statues of Buffy the Vampire Slayer.

To a cynical eye, the reappearance of Famous Monsters and Captain Company might reflect nothing more than an attempt to cash in on the renewed popularity of horror media signaled by the Saw franchise (2003-2010), the Twilight phenomenon, and HBO's True Blood (2008-): an act of exploitation made all the more distasteful by its leveraging of the golden age represented by Ackerman and Famous Monsters. But from another perspective, the cyclical return and self-reinvention of monster culture - understood here as a circulating swarm of texts, objects, and their associated practices - points to deeper mysteries of genre and generation, and the process by which popular culture embeds and reproduces itself within lived practices. 
Writing about fans of Blade Runner (Ridley Scott, 1982), Matt Hills identifies "a strat[um] of fan creators whose desire is to replicate what's seen on screen; to craft and build replica props." This "mimetic fandom" operates in a different realm from other fan activities that transform or rework the text, serving instead to materialize the designed worlds of science fiction in highly skilled ways. (Hills) While the types of prop creation Hills discusses date back at least as far as Star Trek (with fans in the 1970s creating blueprints of ships, sets, and costumes along with mockups of phasers and tricorders), the model kits of monster culture show that the practice of materializing media fictions dates back even further - to a time when, presided over by Ackerman and Famous Monsters, the convergence of horror media and plastic hobbies and crafts encouraged baby boomers to engage with fabrication as an important element of their fandom.

The evolving sophistication of figure kits from the early 1960s to the present day suggests there is much to be learned from longitudinal considerations of object production - how fantasy-media artifacts, in Will Brooker's words, have "grown up along with their audience." (51) Such considerations complicate overly deterministic accounts of how objects are created and sold as part of blockbuster franchise operations. The garage kit movement in particular represents a give-and-take with the agenda of media industries, retrieving errata of lesser-known film and TV properties by incarnating them in plastic, and perhaps encouraging the production of new installments thereby. Even as a transmedia mindset takes hold at the highest levels of media producers who seek ways to multiply their revenue streams and buttress brand identities, the community of kit builders and collectors introduces a productive "noise" of negotiation into market trends.

At the same time, the object practices of monster culture should not be seen as simply a phenomenon in which fan creativity mirrors professional fabrication; rather, they should remind 
us of the way these spheres interpenetrate each other in unstable and overlapping fashion, with objects as implicated in the creation of new texts as they are in those texts' reception. A recent profile of Guillermo del Toro dwells on the filmmaker's memorabilia-stuffed workspace - a personal warehouse of horror, science-fiction, and fantasy materials recalling both the Ackermansion and the myriad "man caves" it inspired - as a monument to his collector's passion as well as a fertile workshop for new projects, such as a planned version of Frankenstein (Zalewski). Del Toro refines his monster designs through a dynamic interplay of illustrations (sketches and drawings) and objects (sculptures and maquettes), fueled by an archive of reference materials that include the horror films beloved by the filmmaker in his youth. "For someone like del Toro, giving birth to a new Frankenstein's Creature is even more exciting than designing an original monster," Zalewski writes. "Just as a Renaissance painter relished the challenge of rendering the Crucifixion, a true monster-maker wants to take on the icons." (46) From Aurora's creature kits of the 1960s to the latest digital-effects-filled blockbuster, monsters have remained particularly "buildable," populating not just the workshops and store shelves of fandom but the ways in which horror media themselves are reimagined, rebooted, and relaunched in new forms. Ultimately, an object-practices perspective brings to the fore the physical artifacts and processes by which popular culture both remembers and recreates itself.

\section{WORKS CITED}

Biskind, Peter. Seeing Is Believing: How Hollywood Taught Us to Stop Worrying and Love the Movies. NY: Pantheon, 1983. 
Brooker, Will. "Internet Fandom and the Continuing Narratives of Star Wars, Blade Runner and Alien.” Alien Zone II: The Spaces of Science Fiction Cinema. Ed. Annette Kuhn. London: Verso, 1999. 50-72.

Caldwell, John Thornton. Production Culture: Industrial Reflexivity and Critical Practice in Film and Television. Durham: Duke U P, 2008.

Chudacoff, Howard P. Children at Play: An American History. New York: New York U P, 2007. Coppa, Francesca. “A Brief History of Media Fandom.” Fan Fiction and Fan Communities in the Age of the Internet. Eds. Karen Hellekson and Kristina Busse. Jefferson, NC: McFarland and Co, 2006. 41-59.

Deshane, Brock. "Backyard Monsters: Equinox and the Triumph of Love.” 11-25. Booklet with Criterion DVD. 2006.

Gelber, Steven M. Hobbies: Leisure and the Culture of Work in America. New York: Columbia U P, 1999.

Graham, Thomas. Aurora Model Kits. 2nd Ed. Atglen, PA: Schiffer Publishing, 2006.

Gray, Jonathan. Show Sold Separately: Promos, Spoilers, and Other Media Paratexts. New York: New York U P, 2010.

Heffernan, Kevin. Ghouls, Gimmicks, and Gold: Horror Films and the American Movie Business, 1953-1968. Durham, NC: Duke U P, 2004. 
Hills, Matt. "As Seen on Screen? Mimetic SF Fandom and The Crafting of Replica(nt)s.” In Media Res: September 10, 2010. http://mediacommons.futureofthebook.org/imr/2010/09/10/

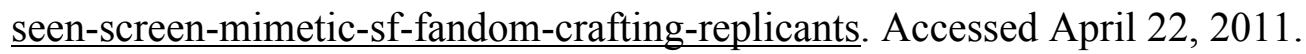

Jenkins, Henry. Convergence Culture: Where Old and New Media Collide. New York: New York U P, 2006.

Jerslev, Anne. "Sacred Viewing: Emotional Responses to The Lord of the Rings." The Lord of the Rings: Popular Culture in Global Context. Ed. Ernest Mathijs. London: Wallflower P, 2006. 206-221.

Johnson, Derek. Creative License: Media Franchising and the Collaborative Production of Culture. New York: New York U P. (Forthcoming)

Kerr, Carson. “Modelmakers In a Tizzy.” Popular Mechanics 6.114: December 1960. 81-86, 256.

Kim, Philip and Michael Heisler. “Opening Wounds.” Famous Monsters of Filmland 251 (July 2010). 4.

Kline, Stephen. Out of the Garden: Toys, TV, and Children's Culture in the Age of Marketing. London: Verso, 1993.

Klinger, Barbara. "Becoming Cult: The Big Lebowski, Replay Culture and Male Fans." Screen 51(1): 2010. 1-20.

Linn, Susan. Consuming Kids: The Hostile Takeover of Childhood. New York: The New P, 2004. 
Pierson, Michele. Special Effects: Still in Search of Wonder. New York: Columbia U P, 2002.

Skal, David J. The Monster Show: A Cultural History of Horror. New York: W. W. Norton \& Company, 1993.

Webb, Terry J. Revenge of the Garage Kit that Ate My Wallet. Duluth, MN: Davidson Printing Company, 1994.

Wasko, Janet and Govind Shanadi. "More than Just Rings: Merchandise for Them All." The Lord of the Rings: Popular Culture in Global Context. Ed. Ernest Mathijs. London: Wallflower P, 2006. 23-42.

Weaver, Tom, with Michael Brunas and John Brunas. Universal Horrors: The Studio's Classic Films, 1931-1946. Jefferson, NC: McFarland, 2007.

Young, Clive. Homemade Hollywood: Fans Behind the Camera. New York: Continuum, 2008.

Zalewski, Daniel. "Show the Monster." The New Yorker, February 7, 2011. 40-53.

Zimmerman, Patricia R. Reel Families: A Social History of Amateur Film. Bloomington: Indiana U P, 1995. 